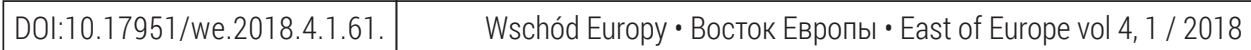

Usov Pavel

Center for Political Analysis and Prognosis

Belarusian Centre for European Studies

\title{
Characteristics of the Belarusian media system
}

Media system understood as the total of mechanisms and technical means of passing information, media institutions and communication and transmission channels between the society and government has been analyzed as a self-sufficient social mechanism especially in the democratic countries. Its influence on the public opinion, on the one hand involves affecting the government and decision-making process, and on the other one it is strong enough to call the media the fourth power.

\section{Mass media and political system}

It may be the subject of a long discussion whether the media are really able to be self-sufficient and independent from the business, interests groups and political affiliation in the democratic countries. And if their sole task is to inform citizens and if they are not used for manipulation of public awareness to achieve political or business goals of specific groups and consequently, what makes the media independent"1.

No one is under the illusion that the media are used as a tool of manipulation in the democratic countries as well but at the same time it should be remembered that irrespectively from the fact who and how uses the media, in democratic societies there cannot take place a situation in which the most important media are focused in the hands of a single political group (a party) or are controlled by the state. That kind of pluralism is one of the basic and most essential elements of a democratic country as Robert Dahl emphasized. "Freedom of speech and access to the alternative and independent sources of information is one of the crucial criterion of a democratic country... Citizens must have access to the alternative sources of information which are not controlled by the government and are not dominated by a single group or a single view"2. In other words, no democratic can exist without pluralism of the media and easy access to the alternative sources of information.

R. Dahl, On Democracy, Yale University Press 1998, p. 97.

2 Ibid., p. 97. 
Some balance in creating of the information and communication space in the democratic countries is guaranteed by the law (the Constitution) which all political actors have to be subject to.

\section{Society ----- Government ---- Media}

Illustration 1. Agreed model of the media functioning in a democratic country

The Internet era together with the epoch of the network society expands the opportunity of citizens to access alternative sources of information even in the non-democratic systems such as Russia or Belarus. Moreover, authoritarian regimes want to manifest on the international arena the fact that they are democratic and thus, they may allow for the certain degree of pluralism of opinions and even criticism of the government. However, this type of pluralism of artificial character plays exclusively manipulative function (for example, the participation of opposition candidates in the elections or functioning of opposition parties in general). It is directed outside and serves diplomatic purpose to prevent external criticism and isolation. At this point, the term of "access to the alternative media" needs to be corrected.

Firstly, alternative or independent sources of information should exist in the traditional system of communication (the print and TV) to which every citizen has the free and unlimited access and not exclusively in the network, or the Internet environment;

Secondly, the communication of alternative information or functioning of the independent sources of information should not be the subject to any restrictions, pressure or limitation imposed by the group in power;

Thirdly, in the political system there is no visible political and ideological domination of the media oriented at the government.

\subsection{System and anti-system media}

In non-democratic countries the conditions of functioning of the independent media are not respected and the whole media system is considerably subordinated to the central government. That also means that the mass media cannot constitute the mechanism affecting the decision-making process and restricting the activity of the government as well as they are not able to defend citizens' freedoms and interests. Due to their being subject to the constant control of the authority, they become one of the most significant sources that allows to control and monitor the process of "proper" development of citizens' awareness and views, which results in the establishment of a relatively coherent and uniform political and information system. 


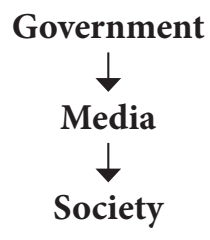

Illustration 2. Agreed model of the location of the media in a non-democratic system

As a result of this political amalgam, the media become a part of the operating political regime (system) and may be referred to as the system and state ones. Everything that does not address the interest of the authoritarian state (including means of communication) and harms or may harm its stability and safety is excluded outside the framework of the political system and is exposed to the constant oppression and persecutions by the government. The subjects representing different views and opinions are generally defined as independent, oppositional or even anti-system as they strive for changes or overthrow of the existing political order.

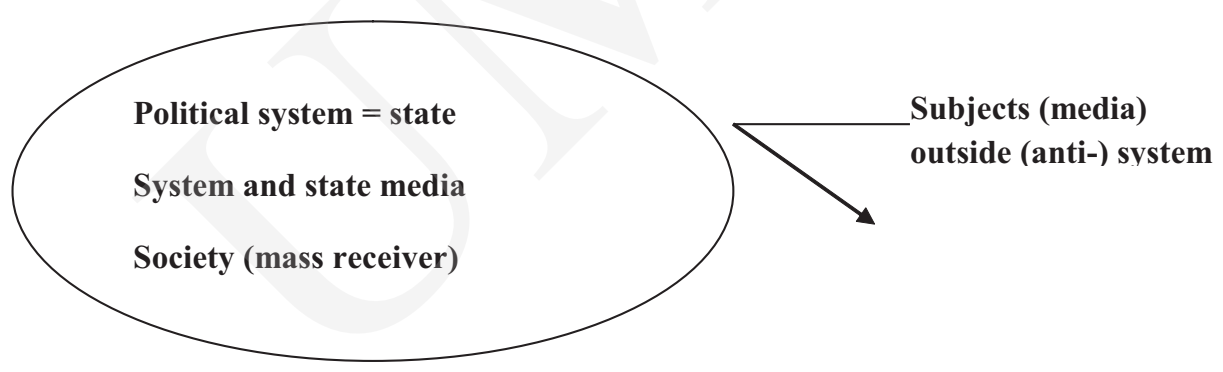

Illustration 3. Agreed model of the division of the media in non-democratic countries

\subsection{Functions of the media in non-democratic countries}

The main tasks of the system and state media in Belarus are as following: informative support of the governmental activity, neutralization of critical opinions and substantial exclusion or distortion of alternative information contradicting the official position or any political alternative from the mass information space. If there are any explicit references made to the opposition, they are usually negative and offensive and the opposition itself is characterized as hostile and destructive.

The Belarusian ideologists very precisely characterize the place and goals of the media in the state system of Belarus: "A very important task of the young Belarusian state is to fight with the manipulation of the public opinion, imposing of foreign (Western) ideology and morality. The media play a key role in solving of this issue and therefore, they should effectively counteract the information pressure exerted by the foreign mass media and shape a positive image of the country. It is unacceptable to use 
the television, radio and press to manipulate public awareness, impose reaction views and hamper the Belarusian government"s.

As an instrument of propaganda and ideology, the system media become one of the key state institutions guaranteeing the stability and legitimization of the authoritarian regime. "Agitation and propaganda are to explain the goals of the Belarusian society, indicate methods of solving of the basic tasks in the social, economic, political and cultural development of Belarus and facilitate the strengthening of the Belarusian statehood. The aim is to present the achievements of the Belarusian society in a convincing way as well as to reveal the essence of the Belarusian course of development. Our propaganda is to introduce spirituality to the Belarusian citizens' awareness and help them to be feel as active builders of the strong and blossoming Belarus"4. In fact, the media in the authoritarian countries such as Belarus are the instrument necessary to create an alternative reality in which the government functions to the benefit of the society, efficiently fights enemies and achieves great economic and political successes.

Consequently, the system media receive unlimited financial and administrative support and all technical means and channels of access to the mass audience. In fact, the media in Belarus may really be referred to as the mass media due to the fact that they have the monopoly for the processing and passing of the information to the greatest number of receivers.

Anti-system media are in fact situated in a kind of ghetto where they have to function in very tight space because of the regime policy. They are deprived of technical (e.g. TV) and legal possibilities to become the mass means of communication. At the same time, a mass receiver does not have an easy access to the alternative sources of information. In fact, the main receiver of alternative information, or in other words, the audience and readers of the anti-system media are people representing the part of the society that shares democratic views. However, this part does not constitute the majority which remains under the influence of the system media.

\section{Structure and operating ways of the system media in Belarus}

The operation of the media system in Belarus is generally supervised by the Ministry of Information. The basic functioning of the Ministry in that area is regulated by the presidential decrees and involves "the state regulation in the sphere of transfer and dissemination of information"s. The Ministry has unlimited possibilities to control and censor the information and content and due to this fact it may also issue warnings and withdraw permits for various media functioning in the territory of Belarus. The withdrawal of permits is in fact a means of pressure on the independent media as the banning of the journalistic activity leads to the use of administrative measures such as, for

\footnotetext{
E.V. Matusevich, S.G. Parechina Ideologicheskaja rabota v Respublikie Belarus': V pomoshch ideologicheskomu aktivu, Minsk: Akademija Upravlenija pri prizedente Respubliki Belarus 2005, p. 7.

4 Ibid, p. 11.

5 Указ Президента Республики Беларусь от 24.09.2001г. №516
} 
example, financial penalties imposed on the banned publishing houses. Additionally, the Ministry has also received the competences of the law enforcement organs thanks to which it was able to prosecute publishing houses and journalists for any activity contrary to the norms established by the state/Ministry ${ }^{6}$.

\subsection{The print}

The Ministry also reserves the exclusive right to distribute the printed products such as newspapers, magazines, periodicals and even books both through subscription and the retail centers. Those trade establishments and centers were united under a single system called "Belsojuzduk" which had been established yet in the period of the USSR. Today, the system consists of 1450 retailers all over the country ${ }^{7}$. In fact, this is the only channel through which the press products (mainly newspapers and magazines) can reach a mass reader. In the case of political necessity or imposing of a sanction on an independent publishing house, the Ministry of Information may prohibit the sale of newspapers by its (single as a matter of fact) trading network. That type of situations usually takes place in the period of important political events when it is essential to maximize the neutralization of the alternative information transfer. wydarzen politycznych w celu maksymalnej neutralizacji przekazu alternatywnej informacji.

The following media are subordinated to the Ministry of Information: the newspaper „Zwiazda” (circulation of 20,000, released every day), two out of three national TV stations (Capital TV and the Second National TV - ONT). One of the biggest Belarusian telecommunications operators responsible for the distribution of cable TV and the Internet also belongs to the structures of the Ministry which obviously gives the Ministry opportunity to determine the package of programs available in TV. Consequently, also cable TV was also covered by control of the government.

At this point it is worth mentioning the following example. On April 1st, 2009, the Belarusian government decided to suspend broadcasting via cable TV of the five Russian TV programs: REN-TV, Channel One, World network, TVC - International, „RTR - Planet”, and „NTV - MIR". They were temporarily replaced by the entertainment programs. The main reason for that measure was the constant criticism of the policy of Alexander Lukashenka and scoffing at his private life (Lukashenka frequently appeared with his four-yea-old son, Nikolai at the official meetings) in the Russian programs broadcast via cable TV.

While mentioning the Russian media, it should be emphasized that for a number of years, practically until 2014 they had been considered as the source of alternative,

6 ПОЛОЖЕНИЕ о Министерстве информации Республики Беларусь, УТВЕРЖДЕНО Постановлением Совета Министров Республики Беларусь 26.10.2001 № 1545

7 Official website of the „Sojuzpiechat”, http://souzpechat.by/history, inf. of 15 XI 2017.

8 V Belorussii ogranichivajut veshchanije rossijskich telekanalov, Lenta.ru 31 IV 2009, https://lenta.ru/ news/2009/03/31/channel/, inf. of 15 XI 2017. 
anti-regime and even pro-democratic information about the events in Belarus. Consequently, Russia was considered to be the engine of democratization of Belarus9.

In this way the Belarusian state exerts political and administrative control over the most significant centers and ways of information transfer that can affect the process of shaping of public opinion and restricts the free access to alternative sources of information for the majority of society.

According to the data from the Ministry of Information, in Belarus there are 1654 registered printed media, 437 are state-funded and 1217 are non-state funded ${ }^{10}$. The difference between the state-funded and non-state funded media basically refers to the fact that the state newspapers and magazines receive the direct financial support from the central or regional budget and they are the main advocates of the central and local government. As a consequence, the non-statehood of other media does not mean imply their political independence. Moreover, most of them are commercial, entertainment or advertising titles. Only 5 of them legally operating in the Belarusian information space may be called truly independent and opposition newspapers. They include the following titles: Nowy Chas, Swobodnyje Nowosti Plus, Nasza Niwa, Narodnaja Wola, Belorusy i Rynok, Belgazeta. In spite of the fact that these newspapers are nationwide which theoretically means that they could be provide information to the mass reader, their circulation oscillates within the range of 8,000 copies, which does not give them an opportunity to reach masses of people. To compare, the circulations of the state newspapers are as follows: Belarus Segodnia-400,000, 7 dniej-40,000, Belorusskaja Niwa-35,000, Zwiazda-20,000. Visible discrepancy in the circulations is the result of the deliberate policy of the government aiming at the restriction of the influence of the independent media and comprehensive support of the state media.

One of the methods of implementation of the state newspapers among the citizens is a compulsory subscription of the nationwide and regional newspapers by the employees of the state institutions, for example: public officers, teachers, lecturers and even students. ${ }^{11}$ The purpose of the obligatory subscription is not only politicizing and ideologization of certain social groups but also transfer of the financing of unprofitable publishing houses to the society. Such a practice of the Belarusian state is also implemented in other areas, for instance, in the so-called "Subbotniki"- when the citizens employed in the state institutions and companies are made to work "voluntarily" for the sake of the state. Compulsory subscription is also the method of shaping of the mindless obedience and humility to the authoritarian state.

9 Rossjiskije pravozashchitniki prizyvajut Kreml pomoch demokratizirovat Belarus, „Belorusskij Partizan”, 18 I 2012, http://www.belaruspartisan.org/politic/201957/, inf. of 01 XI 2017.

10 Official website of the Ministry of Information of the Republic of BelarusOficjalna strona Ministerstwa Informacji Republiki Białoruś, http://mininform.gov.by/ru/statistica-ru/, inf. of 14 XI 2017.

11 Ispovied' shkolnogo direktora, www.obrazovanie.by, 27 V 2017, http://obrazovanie.by/01_ articles/11_116.html, inf. of 26 XI 2017. 


\subsection{Television}

Television still remains the main source of information and shaping of the Belarusian citizens' views and the most powerful instrument of propaganda and manipulation. This tool is totally focused in the hands of the government. The three state TV stations operate on the territory of Belarus: STV (Capital TV), ONT (the second state TV station) (the Ministry of Information) and BT-1 - the National Radio and Television Company of the Republic of Belarus (NPKRT).

By 2001 the only state TV channel had been BT (Belarusian Television). Thus, the TV market had been largely influenced (and still is) by the Russian mass media attracting considerably greater audience than the state media. The most significant Russian channels on the Belarusian TV market were: RTR ("Russian Tele-radio"), NTV ("Independent TV"), ORT ("Social Channel of Russia") and "Culture". ORT was the most popular TV station then with the audience of $83,3 \%$ people. The remaining TV stations had the following audience figures: RTR $-60 \%$, NTV $-42,3 \%$ and BTaround $47 \%{ }^{12}$. Due to the fact that the Russian TV was rather critical when it came to Alexander Lukashenka and political events in Belarus, and on numerous occasions it invited the representatives of the Belarusian opposition which resulted in the rise of the anti-Lukashenka sentiments, they decided to launch new state-controlled TV companies, such as for example, ONT.

On May 1st, 2001, on the basis of the special decree of president Lukashenka, " The second state channel" started to operate. Its launch on the media market was to serve the following purposes:

1. Open and covert promotion of the official political doctrine of the ruling elite.

2. Politicizing of the society and its mobilization around the figure of the president enhanced by the regular outflow of the information. That was the most visible in the period of the referendum and election campaign in autumn 2004.

3. Interference in broadcasting of the alternative means of communication. The transmission of ONT was conducted on the frequency of the most popular channel among Belarussians - ORT. Identical news and information programs of ONT replaced the ones broadcast by ORT. In this way, ONT almost completely substituted the Russian TV channel on the media market.

According to the official data, at the beginning of $2003,72,8 \%$ of the Belarusian population watched ONT. ${ }^{13}$

By 2010 the terrestrial state TV had almost entirely replaced the Russian TV programs. The surveys indicated that $92,2 \%$ of citizens viewed the state programs of the public Belarussian $\mathrm{TV}^{14}$. However, the Russian TV still had a lot of possibilities to

12 M. N. Hurs, Dynamika obshchestvennogo mnienija o socjalno-politicheskoj situacii v Belarusi, Minsk 2003, p. 14.

13 Ibid., p. 16.

14 'Nacionalnyj opros v Marte 2009 roku', NISEPI, http://www.iiseps.org/data09-013.html, inf. of 07 X 2009. 
broadcast in Belarus which negatively affected the assessment of the events in Ukraine of 2014.

In Belarus itself there exists no private or commercial TV that could provide the alternative information content for the mass scale. From the technical point of view, the state TV, mainly NPKRT, embraces the whole information space. Its structure consists of 7 nationwide TV channels including regional ones and the most important nationwide radio stations.

The TV channels (mostly Russian and only by 2014) available partly via satellite or cable way have remained the independent sources of information.

\section{Conditions of independent media functioning}

The analysis of the state information and media policy shows that the activity of the independent media in Belarus is very limited. This concerns not only the access to technical means of communication which are monopolized by the state but also the implementation of its basic functions. The independent media struggle with numerous administrative obstacles connected with creation, transmission and provision of the alternative information to the citizens. Apart from the obstacles associated with the free functioning of the independent media, the journalists of the opposition publishing houses and TV stations experience the permanent pressure from the state.

According to the data obtained from the Belarusian Association of Journalists, in 2015 there were 28 court trials involving the journalists who were punished with very high fines; in 2016- 10 trials and in 2017 as many as 55 trials with the total sum of financial penalties equal 18,000 euros. (The average salary in Belarus is 250 euros) ${ }^{15}$. Apart from administrative persecutions, the government uses various methods of psychological harassment, for example the threat to take away children ${ }^{16}$.

The level of repressions towards the journalists drastically increases in the period of serious political events occurring in the country. It is worth noting that in the conditions of intense political neutralization of the opposition, the journalists and the independent media started to play the role of political leaders mobilizing the social protes $\mathrm{t}^{17}$. This kind of situation took place during the latest wave of protests which flooded Belarus in the period from winter to spring 2017. They resulted from the use of Decree No.3, according to which people who did not pay tax within 183 calendar days were submitted to financial penalties or administrative arrest ${ }^{18}$. Very hard economic

15 Штрафыжурналистам по ст 22.9 КоАП, Białoruska Asocjacja Dziennikarzy, 15 XI 2017, https:// baj.by/ru/analytics/shtrafy-zhurnalistam-po-st-229-koap-tablica-obnovlyaetsya, inf. of 15 XI 2017.

16 A. Smirnov, Belorusskie vlasti daviat na oppoziciju cherez detej, Deutsche Welle, 15 V 2017, http:// www.dw.com/ru/, inf. of 21 XI 2017.

17 M. Andreeva, Żurnalisty privniesli v protesty novuju volnu, Центр Политического Анализа и Прогнозов, 20 III 2017, http://ceapp.info/2017/03/pavel-usov-zhurnalisty-privnesli-v-belorusskieprotesty-novuyu-volnu/,, inf. of 21 XI 2017.

18 Декрет Президента Республики Беларусь №3 «О предупреждении социального иждивенчества», от 22 апреля 2015 года. 
situation in the country together with the absurd policy of the government led to the social outrage, in spread of which the independent media played a very significant role.

The protests which received a colloquial name of "the revolt of freeloaders" revealed the brand new role and significance of the independent media in the conditions of the authoritarian system.

a. Relatively fast informing about the protests and events, mainly by means of the Internet resulted in the engagement into the action of the increasing number of citizens, especially in the regions; through their activities, the media took over the functions of the political organizations, which due to their structural weakness and poor recognition among the citizens were unable to respond to the course of events efficiently;

b. Mobilization of the society by a sort of "information infection", which on the one hand involves the articulation of the citizens' problem and feelings and on the other one is connected with the protest participants' irritation with the government's activities on the mass scale. "Information infection" was possible thanks to on-line reports from the spot of events; it is necessary to point out here that the viewing figures of the independent media increased a hundred times in that period;

c. The journalists, mainly in the regions, became the subjects attracting the protestants and in some cases their presence restrained the authorities from severe actions against the protesting citizens.

Consequently, the active participation of the independent media in the protests provoked the wave of repressions towards the journalists as it was mentioned above.

\subsection{The Internet}

The hostile environment for the functioning of the media in the traditional printed and television space pushed them to the Internet sphere. Fast spread of the Internet in Belarus allowed the independent media to use the Internet as the main tool of dissemination of information to a large part of the society. According to the data obtained from the National Statistical Committee of the republic of Belarus, over $71 \%$ of the citizens use the Internet, and $68 \%$ use it on daily basis ${ }^{19}$. However, it should be remembered that the majority of the users does not use the Internet as the source of access to the alternative information about the political situation in Belarus but rather as the medium of entertainment, business and communication ${ }^{20}$.

In fact, all media centers such as newspapers and radio run their information activity in the Internet and via the Internet. Among the most well-known independent

19 Статистический Ежегодник - 2017. Национальный Статистический Коммитет Республики Беларусь, Минск 2017, р. 350.

20 Статистический Ежегодник - 2016.Национальный Статистический Коммитет Республики Беларусь, Минск 2016, p. 56. 
Internet media are the following: www.Charte97.org, www.Naviny.by, www.belaruspartisan.org, www.svaboda.org, www.euroradio.fm, www.ej.by and many others.

However, the fact that the independent media limit their activity to the Internet, does not mean that this space is free from the government supervision. The Belarusian authorities realize the political function of the Internet and social media. Firstly, the state media are beginning to accustom the Internet actively, for example, www.belta.by, www.sb.by and TV and radio stations. Secondly, technical means of control, providing of information and access to the Internet are state-supervised. The main operators (suppliers) of telecommunication services are the Republican Company "Beltelekom" and the Republican Company "The National Center for Traffic Exchange" established in 2010 pursuant to the president's decree. The control over the technical means allows the Belarusian authorities to cut off and block the access to the most popular Internet media on the territory of Belarus in the periods of tense political situation.

\subsection{Bełsat TV}

One of the unique phenomena in the Belarusian media space is the operation of the independent satellite TV Bełsat. It was established in 2007 with the assistance of the Polish government in order to develop the independent information space that would facilitate democratization of the society. Today Bełsat is one of the most important elements of the Belarusian independent media space. In 2007 its audience was 750,00021. However, the functioning of the Belarusian TV is connected with a couple of difficulties. 1.The official headquarters of TV are situated in Poland so broadcasting is only possible via the satellite or the Internet which reduces the access to its receivers; 2 . The government treats Bełsat as " an enemy TV" which leads to constant arrests and the raids of the militia on the local representatives of Bełsat ${ }^{22}$. The journalists and reporters suffered from the greatest pressure during the wave of protests in Belarus in 2017; 3 . The TV depends on the financial support of the Polish government (the Ministry of Internal Affairs) which poses some risk for its functioning in the case when the policy of the Polish government towards Belarus changes. The problem of exactly this nature ocurred in 2017 when the Polish Ministry (MSZ) decided to terminate cooperation with Bełsat and resigned from financing of the $\mathrm{TV}^{23}$. This decision could have put an end to the ten-year-old Belarusian independent information project. The example of Bełsat also shows to what extent the independent media are sensitive and dependent on a number of external conditions. As we can see, on the one hand, the Belarusian government is interested in the absolute marginalization of the independent media but

21 Nashi zriteli, belsat.eu, http://belsat.eu/ru/about/nashi-zriteli/, inf. of 15 XI 2017.

22 V ofisach "Belsata"v Minske prochodiat obyski, Naviny.by, 31 III 2017, http://naviny.by/ new/20170331/1490945596-v-ofisah-belsata-v-minske-prohodyat-obyski, inf. of 12 XI 2017.

${ }^{23}$ Foreign Minister Witold Waszczykowski gives interview to Wprost weekly. Ministerstwo Spraw Zagranicznych Rzeczpospolitej Polski, 27 XII 2016 http://www.mfa.gov.pl/en/c/MOBILE/news/ foreign_minister_witold_waszczykowski_gives_interview_to_wprost_weekly, inf. of 21 XI 2017. 
on the other one the dependence of the media on the foreign financial support does not guarantee their complete stabilization.

In my opinion, one of the greatest problems of the independent media in Belarus is the lack of foreign Belarusian independent centers or business groups (in Belarus itself, the functioning of independent business groups is illegal) which would be interested in the establishing of independent media centers as it took place in Russia and Ukraine.

\subsection{Structure of independent media}

While analyzing the structure of the Belarusian independent media, I would like to draw attention to the two key aspects: language and geography.

\subsubsection{Language}

Taking into consideration the linguistic aspect, the media may be divided into Belarusian-speaking and Russian-speaking. This language division is connected with the basic functions and tasks determined by relevant information centers.

The function of the Belarusian-speaking media is connected with the willingness to sustain and develop the Belarusian language, which in the period of russification and during Lukashenko's office lost its significance and was practically pushed out of the use not only in in the state and administrative sphere but also in everyday life of Belarussians. Today, the public and information space is dominated by the Russian language. Thus, the task of the editorial offices of the Belarusian media is to develop the language and the national culture in order to widen the social base of democracy and the Belarusian national state.

Indeed, those citizens who speak the Belarusian language are strong proponents of democracy and form the opposition electorate. But the problem connected with the Belarusian language as a basic means of communication is that in a sense, it reduces the audience of the independent media as the majority of the Belarusian citizens (over $70 \%$ ) speaks only Russian. That is why, the Belarusian media (electronic) should give the information in both languages to spread the scope of their receivers ${ }^{24}$.

The Belarusian media involve: Bełsat TV, newspaper „Nasha Niva”, radio station "Svaboda" and „Racja” and the Belarusian editorial office of the Polish Radio for Overseas.

However, there are also numerous Russian-speaking independent media which represent the opinion that in the conditions of various formal restrictions and pressure from the authoritarian government, the independent information should also reach this well-represented group of people whose main language of communication is Russian.

2426 procentov belorusov govoriat doma na belorusskom jazyke, Ежедневник, 21 II 2012, https://ej.by/ news/sociaty/2012/02/21/26_protsentov_belorusov_govoryat_doma_na_belorusskom_yazyke. html, inf. of 22 XI 2017. 
The most recognizable Russian-speaking media are: the Internet media such as www.charter97.org, www.ej.by, www.tut.by, www.belaruspartisan.by, www.naviny.by to mention but a few.

\subsubsection{Geography}

Because of regular repressions from the government, some of the independent media operate from foreign countries, or at least have their official headquarters there. This mainly concerns the radio and TV editorial offices and allows them to function and send the information even in the period of severe waves of pressure when the editorial offices are exposed to raids of the Belarusian militia and special forces which paralyzes their normal activity.

The main place where the Belarusian media are located is Poland due to its geographical proximity and radio reception. Poland houses the offices of Bełsat, radio station Racja, European radio for Belarus and the Belarusian editorial office of the Polish Radio. Karta97 (www.charter97.org) also moved to Warsaw after the mass repressions. The Belarusian editorial office of Radio Svoboda is situated in the Czech Republic.

However, the vast majority of the independent printed media and the Internet ones are still running their activity on the territory of Belarus.

\section{Russian press media in Belarusian media space}

The analysis of the Belarusian media system would not be complete without the evaluation of the place and role of the Russian media in it. It shall be stressed out that the Russian mass media are the key element of the Belarusian media market and insert vast influence on the political and geopolitical orientations of the Belarusian society. Substantially, it may be said that they are over-the-system in their nature because on the one hand they remain outside the control of the Belarusian government, and on the other one they do not serve the interest of the Belarusian political regime but implement the interests of the concrete foreign country which frequently stand in opposition to the interests of Belarus and even to its political regime.

As it was mentioned before, at least to 2013-2014, the Russian media were perceived in a positive way, as a source of alternative information aimed at the support of the Belarusian democratic tendencies. The situation radically changed after the events in Ukraine when the Russian media became the most important tool in the hybrid war and the real backup of the information aggression towards Ukraine. The effect of information influence on the Russian and Ukrainian society was that a considerably numerous number of Belarussians joined "the Russian camp" which supported the activities of Russia in Ukraine and anti-West rhetoric. As a result of the aggressive influence of the Russian media and a relatively passive information policy of the Belarusian state, the majority of Belarussians accepted and still accept the Russian version of the events in Ukraine in the years 2014-2017. For example, 45\% of Belarussians negatively assessed the Ukrainian revolution, $65 \%$ expressed the opinion that the annexation of 
Crimea was justified, 70\% negatively reacted to the Western sanctions imposed on Russia, the number of proponents of the reunification of Russia with Ukraine rose to $13,5 \%$ and finally, a new category appeared constituting $2,3 \%$ of citizens who supported the idea of Belarus to become a part of the Russian Federation ${ }^{25}$. Even today, about $70 \%$ of Belarussians trust the Russian media ${ }^{26}$.

Among the key Russian media which shape the Belarusian information space it is worth mentioning the following ones: daily „Komsomolskaya prawda” - 32,000 copies (on Wednesdays the circulation equals 203,000), newspaper „Arguments and Facts" 120,000; the most important Russian TV stations are: NTV, RTR and ORT. We cannot forget about the role of the Russian social networks such as Vkontaktie and Odnoklassniki which are used by lots of Belarussians and which also efficiently influence the shaping of the public opinion.

The fact that the Belarusian society accepted views and assessment imposed by the Russian media very uncritically can be explained not only by their totally open space. The other explanation is the fact that over the period of 21 years, the Belarusian media, propaganda and ideology used very similar, aggressive rhetoric towards the Belarusian national and democratic tendencies, actively encouraged the idea of integration with Russia, restoration of the political alliance and simultaneously blocked the activity of the independent Belarusian media, which in the eyes of the political elites posed even a greater danger than the Russian media themselves. But when it turned out that Belarus was at the gunpoint of the Russian expansion and Moscow was ready to extend the borders of "the Russian world", which did not necessarily correspond with the interests of the Belarusian political elites, the media in Belarus were not able to adequately react and counteract the Russian information influence.

\section{The Belarusian media: between nationality and statehood}

It might seem that the terms of state media and national media are parallel and coherent and there is not any controversy about it. But that is not the case of Belarus.

The issue is that the state media are not national ones. They do not express any concept or ideology connected with Byelorussianness and the idea of the nation state. This is what distinguishes the Belarusian media system from those of other post-Soviet authoritarian states such as Kazakhstan, Azerbaijan, Russia, etc. Apart from the fact that the media in these countries are politically subordinated to the interests of the ruling elites and included in the process of control and manipulation, they nevertheless constitute an important element of the development and implementation of supra-political ideological concepts. It is to strengthen the sense of consolidation and national unity, to promote the independence foundation, and in the case of Russia, to widespread the

25 Belorusy podderżivajut anneksiu Kryma, no slijannija s Rossijej nie chotiat, Белорусский партизан, 23 IV 2014, http://www.belaruspartisan.org/politic/265044/, inf. of 24 XI 2017.

26 Socopros: belorusy vsio mienshe dovierajut gosSMI, WWW.tut.by, 22 V 2017, https://news.tut.by/ economics/544272.html, inf. of 24 XI 2017 
influence of mega idea of the Russian world onto other countries. That is why, the media in these authoritarian countries can be called the state national. The state, because of the subordination to the government and national - in terms of ideology.

But when it comes to the analysis of the operation of the Belarusian state media, it is easy to notice that the national discourse is completely excluded from the official rhetoric and information space. It is about the fact that the basic language of the communication of the state media is the Russian language. This does not only concern the entertainment programs but also news, analytic and current affair programs. The task of the media is to promote various symbols and motifs from the Soviet period at the same time suppressing those which would Foster culture, history and national consciousness. Such an information policy creates conceptual and ideological emptiness that can be easily filled up with the ideas of "the Russian world" and which uses the messages which are very familiar to a Belarusian receiver.

The main reason for this situation stems from the fact that the Belarusian authoritarian political regime is not based on the national ideology but conversely, it is based on anti-national ideology. The whole of official concept of the today Belarusian state is built up on glorification of everything that is Soviet and on Brotherhood unity with Russia. The official state symbols are the modification of the ones used in the Belarusian Soviet Republic Główna, the names of streets still contain the surnames of communist activists, November 7th, ("October" Revolution Day) is a holiday, the Independence Day is celebrated on July $3^{\text {rd }}$ - the day on which Minsk was liberated from the fascist forces in 1944. "A quarter of century after the collapse of the Soviet Union, the post - Soviet Belarus appears to be more "Soviet" than "-post". Sovietism at the level of symbols obviously affects the system of values and geopolitical orientation in the spiritual sphere"27. That whole ideological superstructure to which the state media are attached influences the character, content and structure of the information and communication space is very close to, and in a sense, integrated with the Russian information space ${ }^{28}$.

Even the Russian aggression in Ukraine did not drastically affect the information policy of the Belarusian state. The Russian media broadcast in the same mode and in comparison to the independent media, have far better conditions of operation and influence on the Belarusian society.

As a consequence, the independent media, apart from the implementation of the function connected with the dissemination of alternative information, have the task to shape the national orientations. The Belarusian media do it in a full way due to the Be-

27 P. Rudkouski, Białoruskie pytania w kontekście europejskich odpowiedzi, KEW Wojnowice 2017, p. 21

28 Usov Pavel: Belorus polnostju integrirovana v “russkij mir", Центр Политического Анализа и Прогнозов 30 I 2015, http://ceapp.info/2015/01/usov-pavel-belarus-polnostyu-integrirovanav-russkij-mir/, inf. of 26. 112017. 
larusian language being the basic language of communication whereas Russian-speaking media do it partly on the basis of creating and passing of the national content.

The general policy of the Belarusian authoritarian regime in the sphere of culture, education and media led to the situation in which the state has practically full control over the process of shaping of the public opinion and citizens' views. However, this does not serve the strengthening of the statehood and the national segment of the Belarusian society but conversely, it approaches its orientation and geopolitical preferences to Russia. On the other hand the regime does everything to weaken the influence of the independent media which attempt to spread democratic values which are directly connected with the values of the independent national state.

\begin{abstract}
The article presents the shape, structure and functioning of the media system in Belarus which substantially depends on the political regime. Thus, The Belarusian media can be divided into the system ones (acting on behalf of and in the interest of the government) and non-system media that present and create alternative information. The text also focuses on the techniques of control over the state media and repressive policy of the authorities towards the independent media. The analysis of the Belarusian media market and the information and communication space would not be complete without the assessment of the role and place of the Russian media in the process of public opinion-forming of Belarussians. This issue as well as the media and information policy of the authoritarian regime are of extreme importance, particularly in the context of the events in Ukraine when the Russian media became the key tool in the so-called hybrid war.
\end{abstract}

Key words: media system in Belarus, media, political regime.

\title{
Charakterystyka białoruskiego sytemu medialnego
}

Streszczenie: $W$ artykule przedstawiono kształt, strukturę i funkcję systemu medialnego na Białorusi, który w sposób faktyczny jest zależny od reżimu politycznego. W związku z tym białoruskie media można podzielić na systemowe (działające na zlecenie i w interesie władzy) oraz pozasystemowe, które tworzą i przedstawiają informację alternatywną. W tekście opisano techniki kontroli funkcjonowania mediów państwowych oraz omówiono represyjną politykę władz wobec mediów niezależnych. Analiza białoruskiego rynku medialnego oraz przestrzeni informacyjno-komunikatywnej nie byłaby pełna bez oceny roli i miejsca rosyjskich mediów w procesie kształtowania opinii publicznej Białorusinów. Wątek ten oraz polityka medialno-informacyjna autorytarnego reżimu robi się ważną i aktualną dla Białorusi w świecie wydarzeń w Ukrainie, kiedy media rosyjskie stały się głównym narzędziem w tak zwanej wojnie hybrydowej.

Słowa kluczowe: system medialny Białorusi, media, reżim polityczny 


\section{Характеристика белорусской медиасистемы}

Аннотация: В статье представлены форма, структура и функции медиасистемы в Беларуси, которая фактически зависит от политического режима. Ввиду этого белорусские СМИ можно разделить на системные (действующие по заказу и в интересах властей) и внесистемные, которые создают и представляют альтернативную информацию. В тексте описаны техники контроля за функционированием государственных средств массовой информации, а также проанализирована репрессивная политика властей в отношении к независимым СМИ. Анализ белорусского медиарынка и информационно-коммуникационного пространства был бы неполным без оценки роли и места российских СМИ в процессе формирования общественного мнения белорусов. Эта тема, а также медиаполитика и информационная политика авторитарного режима, становятся важной и актуальной для Беларуси с точки зрения событий в Украине, когда российские СМИ стали основным инструментом в так называемой гибридной войне.

Ключевые слова: медиасистема Беларуси, медиа, политический режим.

\section{Bibliography/Literature}

\section{Monographs:}

Dahl R. On Democracy, Yale University Press 1998.

Matusevich E.V., Parechina S.G. Ideologicheskaja rabota v Respublikie Belarus': V pomoshch ideologicheskomu aktivu, Minsk: Akademija Upravlenija pri prizedente Respubliki Belarus 2005.

Hurs M. N. Dynamika obshchestvennogo mnienija o socjalno-politicheskoj situaciiv v Belarusi, Minsk 2003. Rudkouski P. Białoruskie pytania w kontekście europejskich odpowiedzi, KEW Wojnowice 2017.

Статистический Ежегодник - 2017. Национальный Статистический Коммитет Республики Беларусь, Минск 2017.

Статистический Ежегодник - 2016. Национальный Статистический Коммитет Республики Беларусь, Минск 2016.

\section{Internet articles:}

Andreeva M. Żurnalisty privniesli v protesty novuju volnu, Центр Политического Анализа и Прогнозов, 20 III 2017, http://ceapp.info/2017/03/pavel-usov-zhurnalisty-privnesli-v-belorusskie-protestynovuyu-volnu/, inf of 21 XI 2017.

Belorusy podderżivajut anneksiu Kryma, no slijannija s Rossijej nie chotiat, Белорусский партизан, 23 IV 2014, http://www.belaruspartisan.org/politic/265044/, inf., of 24 XI 2017.

Foreign Minister Witold Waszczykowski gives interview to Wprost weekly. Ministerstwo Spraw Zagranicznych Rzeczpospolitej Polski, 27 XII 2016 http://www.mfa.gov.pl/en/c/MOBILE/news/

foreign_minister_witold_waszczykowski_gives_interview_to_wprost_weekly, inf., 21 XI 2017. Ispovied' shkolnogo direktora, www.obrazovanie.by, 27 V 2017, http://obrazovanie.by/01_articles/11 _116.html, inf., of 26 XI 2017.

Lukashenko: Nezavisimyj telekanal - „glupyj, bestolkovyj inedriżestvennyj” projek, Tut.by, 26 V 2007, https:/l news.tut.by/politics/86821.html, inf., of 22 XI 2017. 
Pobrane z czasopisma Wschód Europy http://journals.umcs.pl/we

Data: 26/04/2023 12:50:35

Rossjiskije pravozashchitniki prizyvajut Kreml pomoch demokratizirovat Belarus, „Belorusskij Partizan”, 18 | 2012, http://www.belaruspartisan.org/politic/201957. inf. of 01 XI 2017.

Socopros: belorusy vsio mienshe dovierajut gosSMI, WWW.tut.by, 22 V 2017, https://news.tut.by/economics/544272.html, inf., of 24 XI 2017.

Usov Pavel: Belorus polnostju integrirovana v "russkij mir", Центр Политического Анализа и Прогнозов 30 I 2015, http://ceapp.info/2015/01/usov-pavel-belarus-polnostyu-integrirovana-v-russkij-mir/, inf., of 26112017.

V Belorussii ogranichivajut veshchanije rossijskich telekanalov, Lenta.ru 31 IV 2009, https://lenta.ru/ news/2009/03/31/channel/, inf. of 15 XI 2017.

V ofisach "Belsata"v Minske prochodiat obyski, Naviny.by, 31 III 2017, http://naviny.by/new/20170 331/1490945596-v-ofisah-belsata-v-minske-prohodyat-obyski, inf., of 12 XI 2017.

26 procentov belorusov govoriat doma na belorusskom jazyke, Ежедневник, 21 || 2012, https://ej.by/ news/sociaty/2012/02/21/26_protsentov_belorusov_govoryat_doma_na_belorusskom_yazyke. html, inf., of 22 XI 2017.

Штрафы журналистам по ст 22.9 КоАП, Białoruska Asocjacja Dziennikarzy, 15 XI 2017, https://baj. by/ru/analytics/shtrafy-zhurnalistam-po-st-229-koap-tablica-obnovlyaetsya/, inf., of 15 XI 2017.

\section{Official provisions:}

Указ Президента Республики Беларусь от 24.09.2001г. №516.

ПОЛОЖЕНИЕ о Министерстве информации Республики Беларусь, УТВЕРЖДЕНО Постановлением Совета Министров Республики Беларусь 26.10.2001 № 1545.

Декрет Президента Республики Беларусь №3 «0 предупреждении социального иждивенчества», от 22 апреля 2015 года. 